\title{
APRESIASI WARISAN BUDAYA MELALUI HASIL PENELITIAN \\ DALAM PENGEMBANGAN KARAKTER
}

\author{
Cicilia Novi Primiani \\ Disampaikan pada Acara Seminar Nasional SIMBIOSIS II \\ UNIVERSITAS PGRI MADIUN \\ 30 September 2017
}

Perguruan Tinggi merupakan sebuah lembaga untuk mengembangkan ilmu pengetahuan, menyusun/membangun, mengkonservasi/menyimpan dan menyebarluaskan kepada masyarakat. Salah satu peran penting sivitas akademika sebuah perguruan tinggi adalah dosen. Berdasarkan Undang Undang Republik Indonesia Nomor 14 Tahun 2005 tentang Guru dan Dosen, dosen adalah pendidik profesional dan ilmuwan dengan tugas utama mentransformasikan, mengembangkan, dan menyebarluaskan ilmu pengetahuan, teknologi, dan seni melalui pendidikan, penelitian, dan pengabdian kepada masyarakat.

Kegiatan penelitian di sebuah Perguruan Tinggi mempunyai peran sangat besar. Hasil-hasil penelitian inovatif dosen maupun mahasiswa digunakan dan diimplementasikan dalam kegiatan pembelajaran dan pengabdian masyarakat. Kegiatan tersebut dilakukan secara sinergi dan berkelanjutan di bawah kendali lembaga penelitian dan pengabdian masyarakat di perguruan tinggi. Pengembangan dan kendali penelitian haruslah melembaga dalam sebuah perguruan tinggi dan bersinergi dengan rencana strategis perguruan tinggi, sehingga diharapkan produkproduk penelitian dapat sebagai produk unggulan perguruan tinggi. Perguruan Tinggi dapat mengembangkan produk unggulannya bersama mitra industri, dengan harapan akan terjadi sebuah hilirisasi penelitian yang menuju dalam kemandirian sebuah perguruan tinggi.

Sebuah penelitian memiliki kontribusi sangat besar dalam membangun kemandirian bangsa. Peningkatan kemampuan dalam mengadopsi hasil-hasil inovasi penelitian menuntut adanya perubahan budaya dalam rangka peningkatan kemampuan sumber daya manusia sebagai pelaku dalam bidang iptek. Pembudayaan meneliti perlu dibangun sejak dini dan dimulai dari tingkat bawah. Peningkatan kemampuan meneliti seiring dengan kemajuan perkembangan iptek, perlu menekankan pada basis budaya kita sebagai bangsa yang berbudaya. Teknologi itu sendiri juga adalah bagian dari kebudayaan, maka budaya masyarakat haruslah 
dengan sendirinya dituntut agar dapat menyesuaikan dan berkembang sesuai dengan perkembangan teknologi. Membangun budaya meneliti diperlukan sebuah komitmen dan peran serta dari semua pihak yang terkait dalam kegiatan penelitian.

1 Budaya meneliti membutuhkan komitmen baik secara kelembagaan dari pimpinan dan staf di bawahnya, untuk dapat menetapkan secara jelas tujuan penelitian, yang perlu dijabarkan dalam rencana pengembangan penelitian.

2 Budaya meneliti membutuhkan waktu bertahun-tahun untuk dapat berkembang dengan baik dan perlu pemeliharaan rutin. Kebijakan baru perlu ditegakkan secara teratur setiap waktu.

3 Budaya meneliti perlu dibangun mulai sejak dini, dengan penelitianpenelitian sederhana, sehingga di tingkat Perguruan Tinggi yang semula sesuatu yang sangat sulit, menjadi sesuatu yang sangat mudah, bisa dimuali dari konsep $5 \mathrm{SA}$ (5 SA= dipaksa, terpaksa, terbiasa, bisa, luar biasa) (Prof Herawati, 2011).

4 Penanaman nilai karakter terhadap penelitian (jujur, tekun, ulet, semangat, bersosialisasi, kemampuan memecahkan masalah) perlu dibangun dan dikembangkan.

Kegiatan penelitian tidak hanya berbasis ilmiah, pengembangan kognitif, tetapi juga pengembangan nilai-nilai afektif dan psikomotor. Membangun nilai-nilai karakter melalui penelitian sangat perlu ditekankan dalam sebuah proses penelitian, dan tidak hanya berorientasi pada hasil penelitiannya saja. Nilai-nilai kearifan lokal dapat diangkat dalam penelitian serta dapat dikembangkan dan diimplementasikan dalam kehidupan sehari-hari. Tema-tema penelitian berbasis kearifan lokal dapat dikembangkan sebagai sarana pengembangan pendidikan karakter.

Keberagaman sumber daya alam dan keberagaman budaya yang ada di seluruh wilayah Indonesia merupakan potensi untuk dapat dikembangkan dalam penelitian unggulan. Hasil-hasil penelitian dapat dikembangkan dalam kegiatan pembelajaran dan pemberdayaan masyarakat. Salah satu keragaman bahan alam yang dapat dikembangkan dalam penelitian dan pembelajaran karakter adalah budaya pengobatan dengan bahan alam lokal (jamu). Penelitian pengembangan bahan alam lokal untuk pengobatan, dapat ditemukan ada nilai-nilai karakter baik yang dapat diimplementasikan dalam kehidupan sehari-hari. 
Keanekaragaman hayati di Indonesia merupakan sumber daya alam yang dapat dimanfaatkan untuk kesejahteraan manusia dan bukan untuk memiskinkannya, salah satunya dimanfaatkan sebagai bahan obat. Nenek moyang bangsa telah menggunakan sumber daya alam secara cerdas dan bijaksana sebagai bahan-bahan kesehatan. Pengobatan menggunakan bahan alam dilakukan secara turun temurun secara lisan maupun tulisan yang digunakan untuk pencegahan dan pengobatan berbagai penyakit, yang tertuang pada berbagai relief candi dan naskah-naskah Nusantara. Berbagai bahan alam untuk obat diracik sebagai ramuan yang sering disebut jamu. Jamu merupakan salah satu kearifan lokal yang diwariskan dari generasi ke generasi menjadi salah satu pilar kekayaan pengobatan di Indonesia.

Bahan alam yang digunakan dalam bidang kesehatan sering disebut istilah jamu merupakan warisan budaya bangsa yang memiliki nilai-nilai luhur sebagai salah satu potensi kearifan lokal. Jamu yang sudah digunakan oleh nenek moyang bangsa Indonesia mempunyai sebuah filosofi mendalam. Penggunaan jamu oleh nenek moyang sudah sejak ratusan tahun lalu tertuang dalam berbagai relief candi dan naskah kuno yang tersebar di seluruh wilayah Nusantara. Pengunaan bahan alam merupakan bagian yang tidak terpisahkan dengan budaya bangsa itu sendiri.

Alam dan manusia merupakan karya ciptaan yang berada dalam sebuah tatanan sangat baik, dengan pola interaksinya yang saling bersinergi. Nenek moyang bangsa Indonesia telah mengajarkan nilai-nilai luhur tentang segala sesuatu yang diciptakan memiliki makna tersendiri bagi manusia. Berbagai ritual tradisi yang terpahat pada relief candi dan tertulis dalam naskah kuno merupakan bukti warisan budaya bangsa yang bernilai luhur.

Penggunaan bahan-bahan alam (jamu) dalam bidang kesehatan yang sudah dilakukan oleh nenek moyang merupakan sebuah metode pengobatan sebagai nilai kearifan lokal sangat baik, yang diwariskan secara turun temurun. Harmonisasi alam dan manusia merupakan sebuah konsep dasar yang dibangun dalam memaknai penggunaan bahan alam (jamu) sebagai obat sesuai dengan kodrat alam itu sendiri.

Bahan alam yang digunakan sebagai obat merupakan sebuah harmonisasi alam dengan pola sangat ideal. Berbagai senyawa kompleks yang merupakan komponen bahan alam berada dalam sebuah tatanan dengan mekanisme kerja yang saling bersinergi. Kompleksitas senyawa kimia yang terdapat dalam bahan alam berperan 
penting sehingga bahan alam dapat memberikan potensi efektif. Filosofi penggunaan jamu merupakan konsep dasar yang perlu dimaknai, sehingga penggunaan bahan alam (jamu) tidak meninggalkan konsep dasar terhadap harmonisasi kompleksitas senyawa.

Berkembangnya sains dan teknologi secara global, memberi peluang terhadap perkembangan industri farmasi dalam mengembangkan jamu, oleh karena itu standarisasi merupakan tuntutan dalam pemenuhan kualitas dan keilmiahan jamu. Jamu yang dikembangkan dari bahan alam dilakukan dengan cara isolasi komponen aktif dan memformulasikannya sesuai dengan standar kefarmasian. Senyawa hasil isolasi kemudian diidentifikasi rumus kimianya dan disintesis, dianalisis mekanisme serta potensinya dengan uji pre klinis dan klinis pada sistem tubuh secara parsial. Pendekatan reduksionistik dilakukan untuk proses analisis bahan alam yang difokuskan pada satu senyawa tunggal yang dianggap aktif dan berpotensi.

Rangkaian proses panjang yang terjadi dalam upaya peningkatan nilai ilmiah jamu memiliki beberapa kelemahan dan efek negatif dalam tubuh, disamping itu harganya menjadi lebih mahal. Standarisasi untuk memenuhi kebutuhan industri farmasi membutuhkan banyak tenaga ahli, sarana prasarana serta fasilitas kesehatan yang memenuhi syarat. Upaya untuk peningkatan kebutuhan kesehatan masih kesulitan karena masyarakat Indonesia tersebar luas dan banyak yang mendiami daerah terpencil jauh dari fasilitas kesehatan. Salah satu potensi yang dapat dilakukan adalah dengan memanfaatkan bahan-bahan alam dalam memenuhi kesehatan masayarakat.

Penggunaan jamu seharusnya sangat sederhana seperti seduhan, perasan, atau dimakan langsung menjadi sangat rumit, demikian juga dengan pendekatan reduksionistik mendominasi teknologi kesehatan, sehingga semakin mengecilkan konsep berpikir holistik yang sesungguhnya merupakan sebuah filosofi untuk lebih dekat dengan karakter alam sebagai dasar penjaminan kualitas hidup manusia. Upaya melakukan apresiasi jamu diperlukan sebuah konsep dan filosofi secara mendalam, sehingga pemikiran holistik terhadap kompleksitas senyawa bahan alam perlu dikembangkan untuk kepentingan manusia, dan bukan sebagai konteks bisnis.

Modernisasi dan kemajuan teknologi farmasi menyebabkan perubahan secara menyeluruh terhadap penggunaan bahan alam sebagai bahan berkasiat obat. 
Penelitian-penelitian terhadap potensi bahan alam dilakukan secara teliti dan terus menerus menggunakan teknologi canggih adanya komponen-komponen yang berkasiat, dibuktikan dengan berbagai metode analisis seperti aktivitas farmakologi, toksisitas, dan identifikasi komponen aktifnya. Analisis kasiat bahan alam merupakan faktor penting dalam mengapresiasi bahan alam, tetapi diperlukan pemikiran dan perlakuan terhadap bahan alam secara baik dan benar antara komponen kimia bahan alam dengan sistem biologi tubuh, sehingga terjadi keseimbangan.

Berdasarkan pokok permasalahan yang telah dibahas dalam paragraf-paragraf sebelumnya, nilai-nilai karakter apakah yang dapat dibangun dan dikembangkan dalam sebuah penelitian jamu? Adanya sinergi dan keteraturan satu komponen dengan komponen lain dalam bahan alam dan sistem tubuh, sehingga mampu memberikan multi efek yang lebih potensial. Mengunyah daun untuk digunakan sebagai jamu, merupakan proses sederhana dan poten. Proses mengunyah akan melibatkan beberapa enzim serta komponen lain (gigi, lidah, kelenjar ludah) yang saling bekerja sama, sehingga dapat ditelan dan masuk dalam lambung. Keterkaitan semua komponen memberikan bahan pelajaran kepada kita, untuk dapat saling bekerja sama dan berinteraksi sehingga memberikan potensi lebih baik daripada penggunaan alat alat mesin (blender dan juicer). Keteraturan masing-masing komponen senyawa kimia di dalamnya akan bekerja selalu berada pada porsinya secara proporsional. Hal tersebut mengajarkan kepada kita untuk dapatnya masingmasing menempatkan diri sesuai dengan tugas dan kapasitasnya, dan tidak saling tumpang tindih serta mengambil bagian yang bukan menjadi haknya. Masih banyak contoh yang sangat beragam terkait dengan pengembangan penelitian kearifan lokal untuk dapat dikembangkan dalam membangun karakter bangsa, sehingga memiliki daya saing yang berkarakter. 